\title{
Partial purification and Characterization of Two Pectinases (Polygalacturonase and Pectin lyase) from Papaya Pericarp
}

\section{(Carica papaya cv. solo 8)}

\section{Adingra Kouassi Martial-Didier ${ }^{1}$, Konan Kouassi Hubert ${ }^{2 *}$, Kouadio Eugène Jean Parfait ${ }^{2}$, Yapi Jocelyn Constant ${ }^{2}$ and Tano Kablan ${ }^{1}$}

${ }^{1}$ Laboratoire de Biochimie Alimentaire et de Technologie des Produits Tropicaux de 1'Université

Nangui Abrogoua (Abidjan, Côte d'Ivoire), 02 BP 801 Abidjan 02, Côte d'Ivoire

${ }^{2}$ Laboratoire de Biocatalyse et des Bioprocédés de l'Université Nangui Abrogoua

(Abidjan, Côte d'Ivoire), 02 BP 801 Abidjan 02, Côte d'Ivoire

*Corresponding author

\section{A B S T R A C T}

Plant wastes could be a potential source of novel pectinases for use in various industrial applications due to their broad substrate specificity with high stability under extreme

\section{Keywords}

Biochemical properties, Carica papaya, Pericarp, Polygalacturonase, Pectin lyase, Purification.

Article Info

Accepted:

26 May 2017

Available Online:

10 June 2017 conditions. Therefore, the application conditions of novel pectinases (Polygalacturonase and Pectin lyase) from Carica papaya cv. solo 8 pericarp were optimized in this study. Those enzymes were partially purified by ammonium sulphate precipitation, dialysis and isoelectric focusing. The polygalacturonase and pectin lyase were partially purified 1.3 and 1.26 fold with a yield approximately $20 \%$ and $24 \%$, respectively, following purification with isoelectric focusing. The specific activities of 3.62 and $0.176 \mathrm{UI} / \mathrm{mg}$ for polygalacturonase and pectin lyase enzymes were calculated, respectively. The optimal $\mathrm{pH}$ of 5.0 and 8.0 were obtained for the polygalacturonase and pectin lyase, respectively while an optimal temperature of $45^{\circ} \mathrm{C}$ was obtained for polygalacturonase and $50{ }^{\circ} \mathrm{C}$ for pectin lyase. Polygalacturonase and pectin lyase activities were enhanced by $\mathrm{Na}^{+}, \mathrm{Ca}^{2+}, \mathrm{K}^{+}$, and $\mathrm{Mg}^{2+}$ while EDTA has any effect at all concentrations on pectin lyase activity whereas EDTA was inhibitory to polygalacturonase activity. The results suggest that Carica papaya pericarp peels can be used for value added synthesis of pectinase, an important enzyme with numerous biotechnological applications.

\section{Introduction}

Pectinases are responsible for the degradation of the long and complex molecules called pectin that occur as structural polysaccharides in middle lamella and primary cell wall of higher plant. Depending on their mode of action, the enzymes hydrolyzing pectin are broadly known as pectinases, which include pectin methylesterases (E.C.3.1.1.11), polygalacturonase (PG) (E.C.3.2.1.15) and pectin lyase (PL) (E.C.4.2.2.10) (Kashyap et al., 2001). PG cleaves the polygalacturonic acid backbone of the pectin and reduces the average length of the pectin chains (Baron and Thibault, 1985). The pectin lyases (PL) act on pectins, oligomers and polymers of galacturonic acid by catalyzing the rupture between two galacturonic acid units by a $\beta$ elimination mechanism (Jeantet et al., 2007). Pectinases have been used in various processes and industrials, which in the 
degradation of pectic substances is essential (Favela-Torres et al., 2005). Polygalacturonase and pectin lyase have a great commercial significance in industrial application (Kashyap et al., 2001; Khan et al., 2013; Tu et al., 2013; Kumar and Suneetha, 2014). Whereas most industrial production of pectinases is limited to some species of bacteria, yeast (Gummadi and Panda, 2003; Jayani et al., 2005; Combo et al., 2012). Pectinase enzyme has been the focus of research for many years due to the potential and wide applications in various industrial processes. An increasing demand of pectinase has rendered the need of exploring under product capable of producing novel pectinases with improved activities. The screening realized by Yao (2013) on pectinases showed that their activities were two times higher in the pericarp than papaya pulp at mature stage presenting 1/8 yellow skin. This pericarp (peel) could be valorizing to production of commercial pectinases. This paper describes the partial purification and characterization of polygalacturonase and pectin lyase isolated from Carica papaya pericarp cv. solo 8 .

\section{Materials and Methods}

\section{Plant material and enzyme extraction}

The survey carried on the peel (pericarp) of papayas (Carica papaya cv. solo 8). The ripe papayas are presenting $1 / 8$ of the yellow skin studied in this work, were harvested from a farm near Thomasset (Azaguié), a village located at about $50 \mathrm{~km}$ of north of Felix Houphouet Boigny Airport, Abidjan (Côte d'Ivoire).

The papaya pericarp (50 g) was ground using a blender in $50 \mathrm{ml} \mathrm{NaCl}$ solution $0.9 \%(\mathrm{w} / \mathrm{v})$. The homogenate was subjected to sonication $\left(4{ }^{\circ} \mathrm{C}\right)$ at $50-60 \mathrm{~Hz}$ frequency using a BANDELIN SONOPLUS HD 2200 for 10 min and then centrifuged at $10.000 \mathrm{~g}$ for 30 $\min$ at $4{ }^{\circ} \mathrm{C}$. The supernatant was filtered through cotton wool and was kept refrigerated and used as the crude extract.

\section{Chemicals products}

Polygalacturonic acid, pectin from citrus fruits, bovine serum albumin (BSA) and Bradford reagent were supplied by SigmaAldrich. (St. Louis, MO, USA). The electrophoresis reagents on polyacrylamide gel were supplied by BIO-RAD. All chemicals and reagents used were analytical grade.

\section{Enzyme assay}

The polygalacturonase (PG) activity was determined by a standard colorimetric method of Miller (1959) using 3.5-dinitrosalicylic acid (DNS). $900 \mu \mathrm{l}$ of subtract $(0.5 \%$ of polygalacturonic acid prepared in $100 \mathrm{mM}$ of acetate buffer $\mathrm{pH} 5$ ) was mixed with $100 \mu$ l of enzymatic extract for a total of $1000 \mu$. Then the mixture was incubated at $40{ }^{\circ} \mathrm{C}$ for $15 \mathrm{~min}$. The reaction was stopped by adding $1.5 \mathrm{ml}$ of DNS. After DNS was added the whole mixture was placed in a boiling water bath for 5 min. Finally, the mixture was let to cool down at ambient temperature and the absorbance was read at $540 \mathrm{~nm}$ using a blank (mixture without subtract) and D-galacturonic acid for the standard curve.

The galacturonase activity was expressed as the equivalent of galacturonic acid produced per milligram of protein per minute $(\mu \mathrm{moL} / \mathrm{mg} / \mathrm{min})$.

The pectin lyase (PL) activity was determined using the method of Preiss and Ashwell (1963). An assay mixture $(2.5 \mathrm{ml})$ consisting of a $100 \mathrm{mM}$ Tris- $\mathrm{HCl}$ buffer $\mathrm{pH} 8.0,10 \mathrm{mM}$ $\mathrm{CaCl}_{2}, 0.5 \%$ pectin and enzyme solution was incubated at $40{ }^{\circ} \mathrm{C}$ for $1 \mathrm{~h}$. After incubation, the activity was determined by measuring the absorbance of the reaction mixture at $548 \mathrm{~nm}$. 
One unit of pectin lyase activity was defined as the amount of enzyme present in $1 \mathrm{ml}$ of enzymatic solution which released $1 \mu \mathrm{M}$ galacturonic acid for $1 \mathrm{~min}$.

\section{Protein estimation}

Protein concentrations and elution profiles from chromatographic columns were determined by Bradford method (Bradford, 1976). Bovine serum albumin (BSA) was used as the standard protein.

\section{Partial purification of enzymes}

The Partial purification procedure was carried out in the cold room $\left(4^{\circ} \mathrm{C}\right)$. Fifteen (15) $\mathrm{ml}$ of the enzymatic crude extract of the papaya (Carica papaya L. cv solo 8) pericarp were saturated with different concentrations of ammonium sulphate (20-80 \%) and left with gentle stirring for $24 \mathrm{~h}$ in a refrigerator at $4^{\circ} \mathrm{C}$. The mixture was then centrifuged at $6000 \mathrm{~g}$ for $30 \mathrm{~min}$ at $4^{\circ} \mathrm{C}$ with a refrigerated centrifuge (MIKRO 22R, Hettich). The precipitated proteins contained in the pellet were suspended either in $1 \mathrm{ml}$ acetate buffer (0.1 M pH 5) or $1 \mathrm{ml}$ Tris-HCl buffer $(0.1 \mathrm{M}$ $\mathrm{pH} 8$ ) respectively for PG and PL.

The fractions containing the pectinases activities are pooled and subjected to dialysis. The dialysis extracts were immersed in a large volume of buffer $(0.1 \mathrm{M}$ acetate $\mathrm{pH} 7.5$ or 0.1 $\mathrm{M}$ Tris- $\mathrm{HCl} \mathrm{pH} 7.5$ ) with continuous stirring for $16 \mathrm{~h}$. The membrane having pores allowed small molecules such as ammonium and sulfate ions to cross, while not allowing the large protein molecules to pass through it. Every 4 hours the buffer solution was renewed.

This step made it possible to remove the excess of salt but also the substances of low molecular weight such as the pigments contained in the enzymatic raw extract. The dialyzed extracts were subjected to an isoelectric-focusing technique. To start balancing the ion exchange membranes with a solution of phosphoric acid and sodium hydroxide overnight before using the membranes. This operation consisted in immersing the red anode in a solution of $\mathrm{H}_{3} \mathrm{PO}_{4}(0.1 \mathrm{M})$, the black cathode in a solution of $\mathrm{NaOH}(0.1 \mathrm{M})$. Then the focusing chamber was prepared. This preparation consisted of mixing $100 \mu \mathrm{l}$ of dialyzed extract, $150 \mu \mathrm{l}$ ampholyte (Bio-lyte ${ }^{\circledR}$ 3/10, Bio-Rad Laboratories Hercules) and $2.75 \mathrm{ml}$ of distilled water. Fill the $3 \mathrm{ml}$ syringe with the sample and slowly charge the focus chamber. Then, $6 \mathrm{ml}$ of $0.1 \mathrm{M} \mathrm{H}_{3} \mathrm{PO}_{4}$ and 6 $\mathrm{ml}$ of $0.1 \mathrm{M} \mathrm{NaOH}$ were respectively added to the ventilation hole of the anode (red button) and cathodic (black button) assembly. Finally, the isoelectric focusing was carried out at 350 $\mathrm{V}, 3 \mathrm{~mA}, 25 \mathrm{~W}$ for $1 \mathrm{~h}$. Once the IEF race was completed, the fractions were harvested as quickly as possible to avoid the diffusion of the separated proteins. PG and PL activities were assayed in each fraction to identify the isoelectric point of enzyme isolated from papaya pericarp cv solo 8 .

\section{Electrophoresis of proteins}

The partial purity of the enzymes was analyzed by native-polyacrylamide gel electrophoresis (Native-PAGE) (Laemmli, 1970). Silver staining was employed to identify protein bands.

\section{Enzyme characterization}

\section{Effect of pH}

The influence of $\mathrm{pH}$ on the activity of purified polygalacturonase and pectin lyase were probed at different $\mathrm{pH}$, either in $0.1 \mathrm{M}$ sodium acetate buffer ( $\mathrm{pH} 3.5$ - 5.5), in $0.1 \mathrm{M}$ sodium phosphate buffer $(\mathrm{pH} 5.5-7.5)$ or in $0.1 \mathrm{M}$ Tris-HCl buffer (pH 7.0-9.0). PG and PL 
activities were determined under standard conditions.

\section{pH stability of enzyme}

To determine the $\mathrm{pH}$ stability, the polygalacturonase and pectin lyase were preincubated in $0.1 \mathrm{M}$ acetate buffer $(\mathrm{pH} 3.5-$ 5.5) and 0.1 M Tris- $\mathrm{HCl}$ buffer (pH 7.0-9.0) respectively at $4{ }^{\circ} \mathrm{C}$ for $1 \mathrm{~h}$. Then assayed for polygalacturonase and pectin lyase activities in $0.1 \mathrm{M}$ acetate buffer ( $\mathrm{pH} \mathrm{5)}$ and $0.1 \mathrm{M}$ Tris$\mathrm{HCl}$ buffer (pH 7.5) respectively.

\section{Effect of temperature}

The effect of temperature on polygalacturonase and pectin lyase activities was determined by varying the temperature from 30 to $80{ }^{\circ} \mathrm{C}$ at an interval of $5{ }^{\circ} \mathrm{C}$. The PG and PL activities were assayed as decribed above using polygalacturonic acid and pectin as substrates.

\section{Determination of energy of activation and $Q_{10}$ values}

The energy of activation (Ea) was estimated from the slope of Arrhenius plot obtained by plotting the Log of initial enzyme velocity against the reciprocal of the absolute temperature (Riet and Tramper, 1991).

Initial velocities were determined at different temperatures under standard assay conditions. $\mathrm{Q}_{10}$ values were determined according to the method of Segel (1975).

\section{Influence of metallic ions and EDTA}

The effects of metallic ions $\left(\mathrm{Na}^{+}, \mathrm{K}^{+}, \mathrm{Ca}^{2+}\right.$, $\left.\mathrm{Mg}^{2+}, \mathrm{Ba}^{2+}\right)$ and EDTA were determined by adding into the reaction system individually with the final concentration of $5 \mathrm{mM}, 10 \mathrm{mM}$ and $15 \mathrm{mM}$. The residual activity was determined under the standard condition as describe above. The system without any additive was used as a control.

\section{Results and Discussion}

\section{Partial purification of polygalacturonase and pectin lyase}

A summary of the steps utilized to purify partially the pectinases from papaya cv. solo 8 pericarp was recorded in table 1 . The process of pectinases partial purification was achieved with a protocol consisting of three steps. The crude pectinases were partially purified by ammonium sulphate precipitation, dialysis and isoelectric focusing. This first step ammonium sulphate precipitation $30 \%$ not only concentrates the pectinases but also to eliminate some of the pigments contained in the raw extract (data not shown). The specific activities of polygalacturonase and pectin lyase in the step were evaluated as $2.4 \mathrm{UI} / \mathrm{mg}$ and $0.11 \mathrm{UI} / \mathrm{mg}$, respectively (Table 1). Niharika and Abhishek (2014) also used $30 \%$ ammonium sulphate precipitation as the first step for purification of apple pomace pectinases. Hammed and Alyaa (2010) used also ammonium sulphate precipitation as the first step for the purification of pectin lyase of Erwinia carotovora isolated from the spoilt potatoes. After ammonium sulphate precipitation the second step was dialysis. The increase in the specific activity of polygalacturonase $(2.8 \mathrm{UI} / \mathrm{mg})$ and pectin lyase $(0.14 \mathrm{UI} / \mathrm{mg})$ after dialysis could be explained by a loss of undesired proteins which interfere with the activity of pectinases (Undenwobele et al., 2014). These two first steps of purification (ammonium sulphate precipitation and dialysis) of enzymes have already been reported by Ahmed et al., (2016) in the purification of vegetable pectinases. The last step in the purification (Isoelectric focusing) of the polygalacturonase and pectin lyase isolated from the papaya pericarp cv. solo 8 made it possible to improve the 
purification factor but also to determine the isoelectric point of the enzyme. This step made it possible to improve the specific activity of polygalacturonase (3.62 UI/mg) and pectin lyase $(0.17 \mathrm{UI} / \mathrm{mg})$. Polygalacturonase and pectin lyase were partially purified about 1.3 and 1.26 fold with final proteins of $2.86 \mathrm{mg}$ and $3.56 \mathrm{mg}$, respectively (Fig. 1).

The specific activity of papaya pericarp cv. solo 8 polygalacturonase $(3.62 \mathrm{UI} / \mathrm{mg}$ protein) obtained was less than polygalacturonase of Achaetomium sp. Xz8 (28.122 UI/mg protein) (Tu et al., 2013) and polygalacturonase of Aspergillus niger MTCC 3323 (54.3 UI/mg protein) (Arotupin et al., 2012). Otherwise, specific activity of papaya pericarp cv. solo 8 pectin lyase obtained was also less than pectin lyase of Bacillus subtilis BPLSY1 (58.85 $\mathrm{UI} / \mathrm{mg}$ protein) (Al Balaa et al., 2014). These differences in specific pectinases activities could be explained by the nature of the biological material used, by the technique used for purification and but also because these enzymes were partially purified.

Partial purities of polygalacturonase and pectin lyase were verified by performing native polyacrylamide gel electrophoresis. This electrophoresis shows a single protein task for polygalacturonase and pectin lyase but we remark a few protein tasks in band (Figure 2). This result indicates that those enzymes were partially purified.

\section{Characterization of polygalacturonase and pectin lyase}

The results obtained demonstrated the maximum activities of polygalacturonase and pectin lyase partially isolated from papaya pericarp were observed at $\mathrm{pH} 5.0$ and $\mathrm{pH}$ 8.0, respectively. Maximum polygalacturonase activity at $\mathrm{pH} 5.0$ proves the acidophilic nature of polygalacturonase. The optimum $\mathrm{pH}$ of our findings was similar to the pectinase of
Penicillium varidictum RFC3 and Aspergillus niger (Silva et al., 2002; Fahmy et al., 2008), respectively. The range of $\mathrm{pH}$ at which polygalacturonase activity is maximal is between $\mathrm{pH} 3.5$ and 6.0 (Fenghour et al., 2002; Amande et al., 2013). Polygalacturonase optimum $\mathrm{pH}$ was higher than that of purified polygalacturonase tomato (pH 4.4) (Verlent et al., 2004) and lower than polygalacturonase of kiwi ( $\mathrm{pH}$ 5.5) (Shouqing, 2014), Aspergillus niger and Aspergillus flavus ( $\mathrm{pH}$ 5.5) (Deshmukh et al., 2012) and Bacillus sp. KSM-P 410 (pH 7) (Jayani et al., 2005). Polygalacturonase from Carica papaya pericarp could be favorable for the treatment in acid medium such as papaya juice ( $\mathrm{pH}$ 5.6) (Tu et al., 2013). Whereas maximum pectin lyase activity at $\mathrm{pH}$ 8.0 confirms the alkalophilic nature of pectin lyase partially purified. The optimum $\mathrm{pH}$ of the pectin lyase of the papaya pericarp CV solo 8 is identical to that of Aspergillus niger isolated from orange peel (Batool et al., 2013) and Aspergillus flavus (Yadav et al., 2008). On the other hand, it is lower than the optimum $\mathrm{pH}$ ( $\mathrm{pH} 9.5)$ of pectin lyase isolated from Bacillus subtilis BPLSY1 (Al Balaa et al., 2014).

Polygalacturonase and pectin lyase activities were stable between $\mathrm{pH} 4.5$ and 5.5 in sodium acetate buffer and $\mathrm{pH}$ ranging from $\mathrm{pH} 7.0$ and 9.0, respectively. This $\mathrm{pH}$ range is almost similar to that of the purified polygalacturonase of Penicillium sp. CGMCC 1669 which is between $\mathrm{pH} 4$ and $\mathrm{pH} 6$ (Yuan et al., 2011). These results suggest that this $\mathrm{pH}$ range (4.5-5.5) would be favorable for the expression of the enzyme. This zone could be ideal for clarification of fruit juices which have acidic $\mathrm{pH}$, for the maceration of fruit and vegetables that have acidic $\mathrm{pH}$. Concerning pectin lyase $\mathrm{pH}$ stability, these results suggest that working on this enzymatic activity in a $\mathrm{pH}$ range between 7 and 9; Could be ideal for treatment whose $\mathrm{pH}$ was in a basic medium. 
Table.1 Partial purification procedure of polygalacturonase and Pectin lyase from papaya pericarp cv. Solo 8

\begin{tabular}{llllll}
\hline Purification steps & $\begin{array}{l}\text { Total } \\
\text { protein } \\
(\mathrm{mg})\end{array}$ & $\begin{array}{l}\text { Total } \\
\text { activity } \\
\text { (Units) }\end{array}$ & $\begin{array}{l}\text { Specific } \\
\text { activity } \\
\text { (Units/mg) }\end{array}$ & $\begin{array}{l}\text { Yield } \\
(\%)\end{array}$ & $\begin{array}{l}\text { Purification } \\
\text { fold }\end{array}$ \\
\hline $\begin{array}{l}\text { Crude extract } \\
\text { PG }\end{array}$ & 326.93 & 680 & 2.08 & 100 & 1 \\
PL & 326.93 & 32 & 0.098 & 100 & 1 \\
$(\mathrm{NH} 4)_{2} \mathrm{SO}_{4}$ precipitation & & & & & \\
$\mathrm{PG}$ & 85.8 & 206 & 2.4 & 30.33 & 1.15 \\
$\mathrm{PL}$ & 81.26 & 9.25 & 0.114 & 28.9 & 1.16 \\
Dialysis & & & & & \\
PG & 17.72 & 49.56 & 2.8 & 24.06 & 1.17 \\
PL & 17.90 & 2.5 & 0.140 & 27.03 & 1.23 \\
Isoelecric focusing & & & & & \\
PG & 2.86 & 10.35 & 3.62 & 20.88 & 1.3 \\
PL & 3.52 & 0.62 & 0.176 & 24.8 & 1.26 \\
\hline
\end{tabular}

Table.2 Some physicochemical characteristics of polygalacturonase and pectin lyase from papaya pericarp cv. Solo 8. Values given are the averages of at least three experiments $\pm \mathrm{SE}$

\begin{tabular}{lll}
\hline Physicochemical properties & Values & \\
\hline & $\mathrm{PG}$ & $\mathrm{PL}$ \\
\cline { 2 - 3 } Optimum temperature $\left({ }^{\circ} \mathrm{C}\right)$ & 45 & 50 \\
Optimum $\mathrm{pH}$ & 5.0 & 8.0 \\
pH stability & $4.5-5.5$ & $7.5-9$ \\
Activation energy $(\mathrm{kJ} / \mathrm{mol})$ & $77.12 \pm 0.03$ & $68.77 \pm 0.05$ \\
$\mathrm{Q}_{10}$ & $2.67 \pm 0.1$ & $1.61 \pm 0.1$ \\
Activator agents & $\mathrm{Mg}^{2+}, \mathrm{Ca}^{2+}, \mathrm{K}^{+}, \mathrm{Na}^{+}$ & $\mathrm{Mg}^{2+}, \mathrm{Ca}^{2+} \mathrm{Ba}^{2+}, \mathrm{K}^{+}, \mathrm{Na}^{+}$ \\
Inhibitor agents & $\mathrm{Ba}^{2+}, \mathrm{EDTA}^{\mathrm{a}}$ & - \\
\hline
\end{tabular}

Values given are the averages of at least three experiments \pm SE. a: ethylene diamine tetraacetic acid.

Fig.1 Effect of different ammonium sulphate saturation on polygalacturonase and

Pectin lyase from papaya pericarp

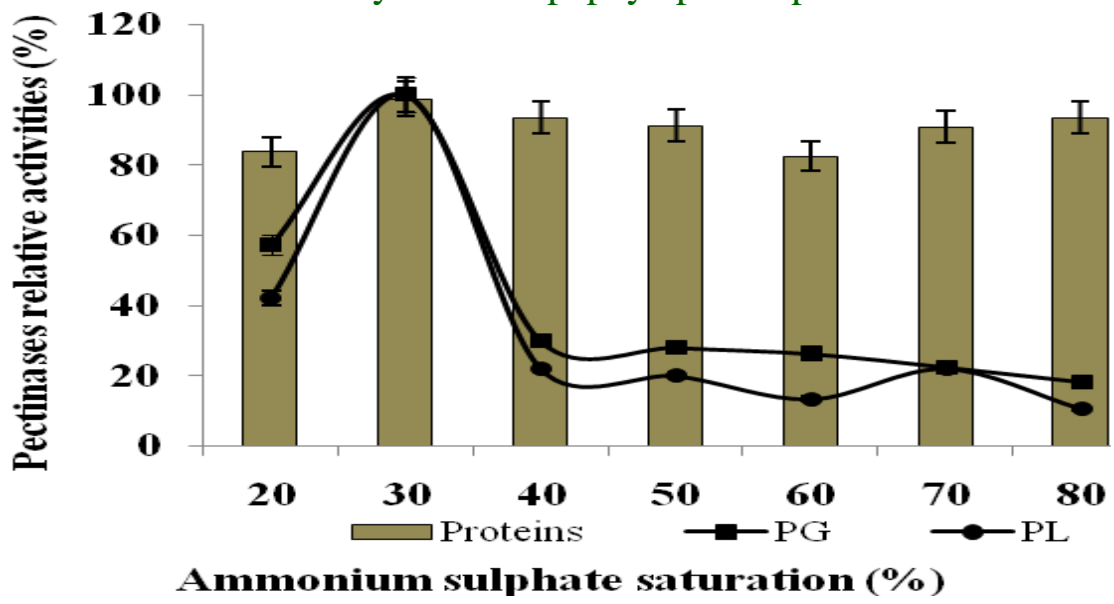


Fig.2 Native-PAGE of papaya pericarp. Lane 1, crude extract; lane 2, Polygalacturonase purified and lane 3 , pectin lyase purified

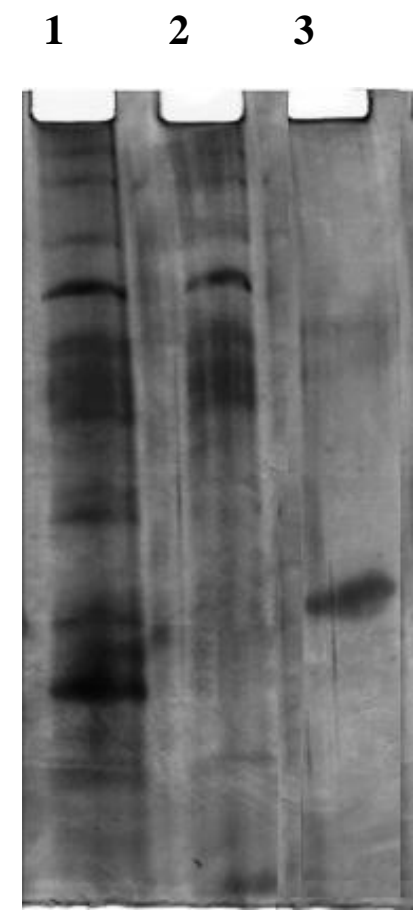

The highest PG and PL activities were observed at $45{ }^{\circ} \mathrm{C}$ and $50{ }^{\circ} \mathrm{C}$, respectively. Papaya pericarp polygalacturonase optimum temperature obtained in this work was in agreement with the polygalacturonase produced by gamma irradiated Penicillium citrinum (El- Batal et al., 2013). This optimum temperature was lower than that of tomato polygalacturonase (Verlent et al., 2004). Indeed, these authors obtained an optimum temperature of $55{ }^{\circ} \mathrm{C}$. In addition partial purified Carica papaya pericarp pectin lyase optimal temperature was $50^{\circ} \mathrm{C}$. This value was lower than pectin lyase from mango peel optimum temperature $\left(60^{\circ} \mathrm{C}\right)$ (Amande et al., 2013). From these results, polygalacturonase and pectin lyase isolated from Carica papaya could be used in food industry for processes requiring moderate temperatures. Those optimum temperatures $\left(45^{\circ} \mathrm{C}\right.$ and $\left.50^{\circ} \mathrm{C}\right)$ were recommended for clarification and depectination operations.
This treatment must be carried at temperatures between 45 and $50{ }^{\circ} \mathrm{C}$ to avoid gelling during clarification operations (Grampp, 1977). These mesophilic enzymes could be coveted in the food industry during thermal operations (Table 2).

During thermal activation, polygalacturonase activation energy $(\mathrm{Ea})$ and pectin lyase $\mathrm{Ea}$ were $77.12 \pm 0.03 \mathrm{~kJ} / \mathrm{mol}$ and $68.77 \pm 0.05$ $\mathrm{kJ} / \mathrm{mol}$ (Figure $4 \mathrm{C}$ and $4 \mathrm{D}$ ) with $\mathrm{Q}_{10}$ values of 2.67 and 1.67, respectively. According to Lee and Wiley (1970) more Ea was high more the reaction was held quickly. The activation energy (Ea) value of the polygalacturonase of Carica papaya pericarp was four times lower than the value founded by Benen et al., (2003) which is $324.17 \mathrm{~kJ} / \mathrm{mol}$ on tomato polygacturonase of variety CXD 199. These results suggest that the polygalacturonase isolated from Carica papaya pericarp cv. solo 
8 reacted less rapidly than polygalacturonase isolated from tomato variety CXD 199.

The activities of polygalacturonase and pectin lyase partially purifies were highly activated by $\mathrm{Mg}^{2+}, \mathrm{Na}^{+}, \mathrm{K}^{+}$and $\mathrm{Ca}^{2+}$ (Figure 5). This result is agreement with Rexova-Benkova (1976) who reported that generally pectinases were activated by the presence of cations. The activation of pectin lyase activity by the $\mathrm{Ca}^{2+}$ was already been reported by several authors (Ren and Kermode, 2000; Arotupin et al., 2012; Pedrolli and Carmona, 2014). According to Al Balaa et al., (2014), in absence of the calcium ion $\left(\mathrm{Ca}^{2+}\right)$ the pectin lyase activity was zero. Whereas, the polygalacturonase activity from Carica papaya pericarp was inhibited by $10 \mathrm{mM}$ and $15 \mathrm{mM} \mathrm{Ba}{ }^{2+}$. However, the result was in contrary to pectinase enzyme from fruit and vegetable wastes and Aspergillus niger strain MCAS2, that $\mathrm{Ba}^{2+}$ ions found to enhance the pectinase activity (Ramachandran and Kurup, 2013; Khatri et al., 2015). This suggests that the requirement of metals ions for the polygalacturonase activity vary depending upon their sources. In addition the inhibitory effect of barium ion would probably be a result of interactions between cations and peptide chains and not directly on the enzyme (Walter, 1991). Then EDTA was an inhibitor of PG activity but had no impact on the pectin lyase activity. Our results were similar to those of Arotupin et al., (2012). These authors confirmed the inhibitory of EDTA in Aspergillus niger CSTRF polygalacturonase. On the other hand, our results are different from those of Whitaker (1984) showed that EDTA was generally an inhibitor of pectin lyase activity due to $\mathrm{Ca}^{2+}$ chelation.

In this study, the partial purification and some characteristics properties of polygalacturonase and pectin lyase extract from Carica papaya cv. solo pericarp were investigated. The polygalacturonase and pectin lyase were partially purified successfully and showed reasonable stability to different conditions. From this characterization of papaya pericarp polygalacturonase and pectin lyase, it may be a potential candidate for industrial uses. Therefore, it can be employed in industries for hydrolysis of pectic biomass to utilizable bio-product. Future studies on pectinases isolated from Carica papaya pericarp should be devoted to the understanding the effect of heat treatment on these enzymes.

\section{Acknowledgments}

The authors would like to acknowledge University of Agricultural Sciences and Veterinary Medicine of Cluj-Napoca, Laboratory of Molecular Nutrition and Proteomics, Institute of Life Sciences, Romania for providing technical support for this work.

This research was supported by "Eugen Ionescu" $\mathrm{PhD}$ research scholarship of the Romania Ministry of Foreign Affairs.

\section{References}

Ahmed, I., M. A., Zia, M. A., Hussain, Z., Akram, M. T., Naveed, and Nowrouzi 2016. Bioprocessing of citrus peel for induced pectinase production by Aspergillus Niger; its purification and characterization. J. Rad. Res. Appl. Sci., 9: 148-154.

Al Balaa, B., R., Esmail, and Yazaji, S. 2014. Purification and characterization of an extracellular alkaline pectate lyase from Bacillus subtilis BPLSY1. Bulg. J. Agric. Sci., 20 (1): 193-198.

Amande, T., B. Adebayo-Tayo, U., NdubuisiNnaji, and Ado, B. 2013. Production and partial characterization of pectinases from mango peels by Aspergillus tamarii. J. Microb. Biotech. 
Food sci., 3(1): 59-62.

Arotupin, D. J., F. A., Akinyosoye, and Onifade, A. K. 2012. Purification, Characterization and Application of Polygalacturonase from Aspergillus niger CSTRF. Malays. J. Microbiol., 8(3): 175-183.

Baron and Thibault, J. F. (1985). Les enzymes pectinolytiques. Dans: Hydrolases et dépolymérases, enzymes d'intérêt industriel. Gauthier-Villars (Ed), Mouranche A., Costes C., pp. 143-164.

Batool S., M. J, Asad, S. M. S., Naqvi1, R. T., Mahmood, A., Guffar, M., Gulfraz, and Hadri, S. H. 2013. Production and partial purification of pectin lyase by Aspergillus niger grown on orange peels. Afr. J. Microbiol. Res., 7(13): 1144-1149.

Benen J. A., G. J., Van Alebeek, and Voragen, A. J. 2003. Pectic esterases. In: Whitaker

R, Voragen AGJ, Wong DWS, editors. Handbook of food enzymology, Marcel Dekker, New York, pp. 849-856.

Bradford, M. M. 1976. A rapid and sensitive methods for the quantitation of microgram quantities of protein utilizing the principle of protein-dye binding. J. Anal. Biochem, 72(1-2): 248-254.

Combo, A. M. M., M., Aguedo, D., Goffin, B., Wathelet, and Paquot, M. 2012. Enzymatic production of pectic oligosaccharides from polygalacturonic acid with commercial pectinase preparations. Food Bioprod. Process, 90: 588-596.

De Vries, R. P., and Visser, J. 2001. Aspergillus Enzymes Involved in Degradation of Plant Cell Wall Polysaccharides. Microbiol. Mol. Biol. $R ., 65(4):$ 497-522.

Deshmukh, N., R, Talkal, K., Jha, P. G., Singh, and Prajapati, D. C. 2012. Production,
Characterization and Comparison of Polygalacturonase from various strains of Aspergillus. Int. J. Sci. Technol., 1(9): 85-91.

El-Batal, A. I., E. M, Osman, and Shaima, I. A. M. 2013. Optimization and characterizationof polygalacturonase enzyme produced by gamma irradiated Penicillium citrinum. J. Chem. Pharm., 5(1): 336-347.

Fahmy, A. S, F. M., El-beih, S. A., Mohamed, S. S., Abdel-Gany, and Abd-Elbaky, E. A. 2008. Characterization of an exopolygalacturonase from Aspergillus niger. Appl. Biochem. Biotechnol, 149: 205-217.

Favela-Torres, E. C., J. C., Aguilar, Contreras-Esqivel, and ViniegraGonzàlez G. 2005. Pectinase. In : Enzyme Technology, Ed. by Pandey A., Webb C., Soccol C. R. and Larroche C. Springer Verlag, Berlin, pp. 273-296.

Fenghour, H., A., Ladjama, and Taibi, Z. 2002. Recherche de l'activité pectinolytique chez 22 souches de champignons microscopiques isolées d'un sol de la region d'El Kala. Technologies Avancées, 14: 1-6.

Grampp, E. 1977. Hot clarification process improves production apple juice concentrate.Food Technol., 31(11): 3843.

Gummadi, S. N., and Panda, T. 2003. Purification and biochemical properties of microbial pectinases. Process Biochem., 38: 987-996.

Hammed, I. M. S. A., and Alyaa, M. 2010. Purification and characterization of extra cellular Pectin lyase from Erwinia carotovora isolate from spoilt potatoes. DJPS, 6(2): 383-397.

Jayani, R. S., S., Saxena, and Gupta, R. 2005. Microbial pectinolytic enzymes: a review. Process Biochem, 40: 29312944.

Jeantet, R., T., Croguennec, P., Schuck, and 
Brulé, G. 2007. Science des aliments: Technologie des produits alimentaire, Edition Tec and Doc, Lavoisier, volume 2, p. 456.

Kashyap, D. R., P. K., Vohra, S., Chopra, and Tewari, R. 2001. Applications of pectinases in the commercial sector: A review. Bioresour. Technol., 77: 215227.

Khan, M., E., Nakkeeran, and UsmeshKumar. 2013. Potential applications of pectinase in developing functional foods. Апnu Rev Food Sci.Technol., 4: 21-34.

Khatri, B. P., T., Bhattarai, S., Shrestha, and Maharjan J. 2015. Alkaline thermostable pectinase enzyme from Aspergillus niger strain MCAS2 isolated from Manaslu Conservation Area, Gorkha, Nepal. SpringerPlus, 4: 488-496.

Kumar, P. G., and Suneetha, V. 2014. A cocktail enzyme-Pectinase from fruit industrial dump sites. Res. J. Pharm. Biol. Chem. Sci., 5(2): 1252-1258.

Laemmli, U. K. 1970. Cleavage of structural proteins during the assembly of the head of bacteriophage T4. Nature, 227: 658685.

Lee, Y. S., and Wiley, R. C. 1970. Measurement and partial characterization of pectinesterase in apple fruits. J. Am. Soc. Hort. Sci., 95: 465-468.

Miller, G. L. 1959. Use of dinitro salicylic acid reagent for the determination of reducing sugars. Anal. Chem., 31: 426428.

Niharika, S., and Abhishek, M. 2014. Purification and characterization of pectinase (pectin methyl esterase) from apple pomace. WJPPS, 4(1): 749-764.

Pedrolli, D. B., and Carmona, E. C. 2014. Purification and Characterization of a Unique

Pectin Lyase from Aspergillus giganteus Able to Release Unsaturated Monogalacturonate during Pectin Degradation. Enzyme Res., 2014: 1-7.

Preiss, J., and Ashwell, G. 1963. Polygalacturonic acid metabolism in bacteria I. Enzymatic formation of 4 uronic acid. J. Biol. Chem., 283: 15711576.

Ramachandran, S. and Kurup, G. 2013. Screening and isolation of pectinase from fruit and vegetable wastes and the use of orange waste as a substrate for pectinase production. Int. Res. J. Biological. Sci., 2 (9):34-39.

Ren, C., and Kermode, A. R. 2000. An Increase in Pectin Methyl Esterase Activity Accompanies Dormancy Breakage and Germination of Yellow Cedar Seeds. Plant Physiol., 124: 231242.

Rexova-Benkova, L., and Markovïc, O. 1976. Pectic enzymes. Adv. Carbohydr. Chem. Biochem., 33: 323-385.

Riet, K. V., and Tramper, J. 1991. Basic bioreactor design. Marcel Dekker, New York, p. 472.

Segel, I. H. (1975).Biochemical calculations: How to Solve Mathematical Problems in General Biochemistry. John Wiley (second Ed.), New York, p. 464.

Shouqing, S. 2014. Data Analysis on Properties of Polygalacturonase Purified and separated From Kiwi fruit. J. Food Sci.Tech, 6(7): 839-842.

Silva D., E. S., Martins, R., Silva, and Gomes, E. 2002. Pectinase production by Penicillium viridicatum RFC3 by solid state fermentation using agro-industrial by-products. Braz. J. Microbiol., 33:318-324.

Tu, T., K., Meng, Y., Bai, P., Shi, H., Luo, Y., Wang, P., Yang, Y., Zhang, and Yao, B. 2013. High-yield production of a lowtemperature-active polygalacturonase for papaya juice clarification. Food Chem., 141: 2974-2981. 
Undenwobele, D. I., C. A., Nsude, A. L., Ezugwu, S. O. O., Eze, C., Anyawu, P. N., Uzoegwu, and Chilaka, F. C. 2014. Extraction, partial purification and characterization of pectinases isolated from Aspergillus species cultured on mango (Mangifera indica) peels. Afr. $J$. Biotechnol., 13(24): 2445-2454.

Verlent, I., A., Van Loey, C., Smout, T., Duvetter, and Hendrickx, M. E. 2004. Purified tomato polygalacturonase activity during thermal and highpressure treatment. Biotechnol. Bioeng, 86(1): 63-71.

Walter, R.H. 1991. The Chemistry and Technology of Pectin. New York: Academic Press, pp. 2-15.

Whitaker, J. R. 1984. Pectic substances, pectic enzymes and haze formation in fruit juices. Enzyme Microb. Technol., 6(8): 341-349.
Yadav, S., P. K., Yadav, D., Yadav, and Yadav, K. D. S. 2008. Purification and characterization of an alkaline pectin lyase from Aspergillus flavus. Process Biochem, 43: 547-552.

Yao, N. B. 2013. Conservation de la papaye (Carica papaya L. var solo 8) par le contrôle du niveau de maturité à la récolte ET des activités biochimiques. Thèse de Doctorat, Université Nangui Abrogoua, Abidjan, Côte d'Ivoire.

Yuan, P., K., Meng, H., Huang, P., Shi, H., Luo, P., Yang, and Yao, B. 2011. A novel acidic and low-temperature-active endo-polygalacturonase from Penicillium sp. CGMCC 1669 with potential for application in apple juice clarification. Food Chem., 129: 13691375.

\section{How to cite this article:}

Adingra Kouassi Martial-Didier, Konan Kouassi Hubert, Kouadio Eugène Jean Parfait, Yapi Jocelyn Constant and Tano Kablan. 2017. Partial Purification and Characterization of Two Pectinases (Polygalacturonase and Pectin Lyase) from Papaya Pericarp (Carica papaya cv. solo 8). Int.J.Curr.Microbiol.App.Sci. 6(6): 2729-2739. doi: https://doi.org/10.20546/ijcmas.2017.606.326 